\title{
Exploration of New Phosphors Using a Mineral-Inspired Approach in Combination with Solution Parallel Synthesis
}

\author{
Masato Kakihana ${ }^{1}$, Jihae Kim ${ }^{1}$, Tetsufumi Komukai ${ }^{2}$, Hideki Kato ${ }^{1}$, Yasushi Sato ${ }^{1}$, \\ Makoto Kobayashi $^{1}$, Yuji Takatsuka ${ }^{2}$ \\ ${ }^{1}$ Institute of Multidisciplinary Research for Advanced Materials, Tohoku University, Sendai, Japan \\ ${ }^{2}$ Ichikawa Research Laboratories, Sumitomo Metal Mining Co. Ltd., Ichikawa, Japan \\ Email: kakihana@tagen.tohoku.ac.jp
}

Received May 29, 2013; revised July 7, 2013; accepted August 1, 2013

Copyright (c) 2013 Masato Kakihana et al. This is an open access article distributed under the Creative Commons Attribution License, which permits unrestricted use, distribution, and reproduction in any medium, provided the original work is properly cited.

\begin{abstract}
The concept, as well as the methodology of using a mineral-inspired approach in combination with solution parallel synthesis (SPS) for exploration of new phosphors among $\mathrm{Na} / \mathrm{Sr}(\mathrm{Ba}) / \mathrm{Al}$-silicate and $\mathrm{Zr}(\mathrm{Ti})$-silicate minerals, is reported. By employing the proposed approach, we have discovered new phosphors of $\mathrm{NaAlSiO}_{4}: \mathrm{Eu}^{2+}$ and $\mathrm{BaZrSi}_{3} \mathrm{O}_{9}: \mathrm{Eu}^{2+}$, that emit green-yellow $(553 \mathrm{~nm})$ and blue-green $(480 \mathrm{~nm})$ light, respectively, when excited by radiation of 290 to $420 \mathrm{~nm}$.
\end{abstract}

Keywords: Mineral; Solution Parallel Synthesis; Exploration of New Phosphors; Silicate

\section{Introduction}

Research aimed at the discovery of new phosphors has been dependent on the knowledge of solid-state physics and crystal chemistry. Generally, the exploration of new phosphors involves the repetition of a sequential process: 1) devising the composition of a chosen candidate substance, 2) its synthesis, 3) characterization of the fluorescence of the synthesized material, 4) modification of the original composition, 5) its re-synthesis, and so on. However, it should be noted that the aforementioned process needs to be repeated several times to develop a new phosphor. Therefore, the process of discovering a new phosphor requires an enormous amount of time and effort. As a consequence, the search for new phosphors was confined to a limited composition range.

One of the effective ways of addressing the challenge is to employ generic algorithm-assisted combinatorial chemistry (GACC), which was applied to the development of heterogeneous catalysts in the recent past [1-3]. GACC has been successfully utilized by Kee-Sun Sohn's group for the exploration of new phosphors for the use in plasma displays and light-emitting diodes (LEDs) [4-8]. More recently, the same research group employed highthroughput combinatorial chemistry in combination with an advanced computational approach based on particle swarm optimization [9], and executed a so-called particle swarm optimization-assisted combinatorial materials search (PSOCMS) to discover novel phosphors such as
$\mathrm{Ce}_{2.6} \mathrm{Ca}_{1.4} \mathrm{Si}_{12} \mathrm{O}_{4.4} \mathrm{~N}_{16.6}: \mathrm{Eu}^{2+}$ and

$\mathrm{La}_{2.544} \mathrm{Ca}_{1.456} \mathrm{Si}_{12} \mathrm{O}_{4.456} \mathrm{~N}_{16.544}: \mathrm{Eu}^{2+}$ [10]. Considerable attention has been paid to the following in both GACC and PSOCMS: 1) development of computational algorithms to make the high-throughput combinatorial screening efficient and 2) shortening of the time needed for the final identification of promising compositions. On the other hand, lesser attention has been devoted to the method of the material fabrication itself although it is crucial to establish the methodology for the reliable synthesis of phosphors, as this ensures homogeneity of compositions and uniform distribution of activators in given host compounds. In most previously reported studies based on GACC/PSOCMS as well as the synthetic studies on phosphors, researchers have primarily relied on the traditional method based on solid-state reactions. As a result, precise control of the compositions of phosphors and achievement of a homogeneous distribution of small amounts of activators in the host compounds were not possible. Therefore, we propose an alternative methodology involving a mineral-inspired approach in combination with the so-called solution parallel synthesis (SPS) method [11].

In the SPS method, tens of types samples are synthesized at once under the same conditions by employing the "polymerizable complex (PC) method" [12-14] or the "amorphous metal complex (AMC) method" [12-14]. This results in relatively simple and efficient screening of 
the phosphor candidate substances, which was difficult through conventional techniques. The PC and AMC methods are best suited for homogeneous synthesis of ceramics with complex compositions. The scheme for the SPS method is summarized in Figure 1. We explored new phosphors containing silicon by focusing on silicon of Clarke number 2 and employing the SPS method. There are more than 18,000 inorganic crystalline compounds containing silicon, a common element [15]. However, since most of them are found in natural minerals, their artificial synthesis is difficult. As a result, their application as functional ceramics, e.g., phosphors, is uncommon.

The obstacle in the artificial syntheses of compounds containing silicon imitating minerals comes from the lack of an appropriate silicon source that is required when an advanced solution technology has to be employed to obtain high-quality Si-containing ceramic materials. In fact, the only silicon sources that can be used in a given solution process are "volatile" tetraalkoxysilanes (TAS). However, the use of TAS is not recommended, since TAS evaporates when subjected to repeated heat treatment, as a result of which the composition changes greatly from the original. For this reason, the discovery of new phosphors from silicon-containing compounds regarded as cornucopia of functions is challenging. We systematically synthesized silicon-containing phosphors

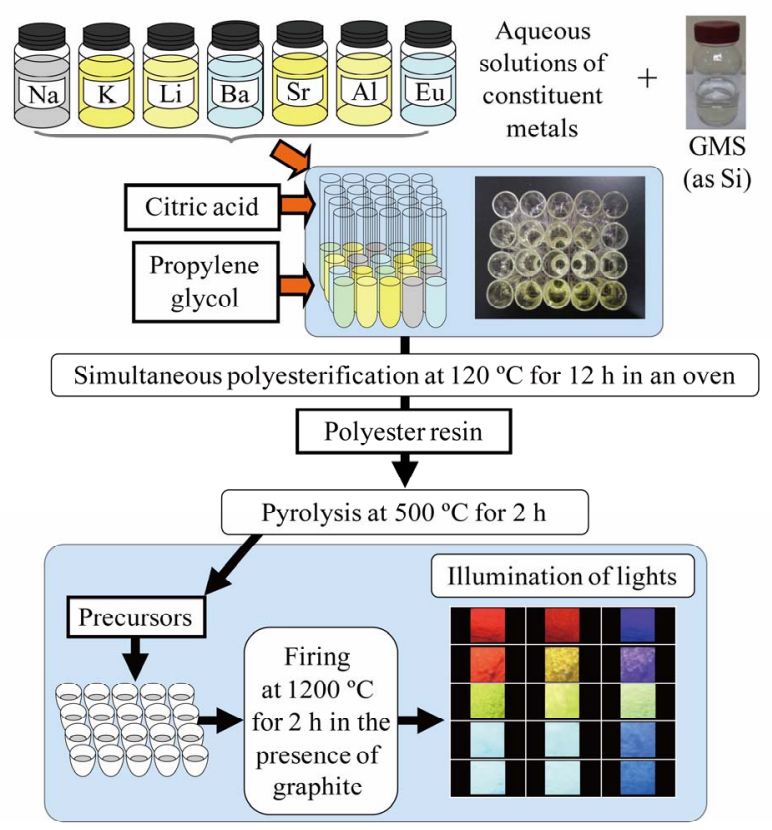

Figure 1. Scheme of solution parallel synthesis scheme for exploration of new phosphors in $\mathrm{A}_{x} \mathrm{~B}_{y} \mathrm{Al}_{z} \mathrm{Si}_{q} \mathrm{O}_{w}: \mathrm{Eu}^{2+}(\mathrm{A}=\mathrm{Li}$, $\mathrm{Na}, \mathrm{K} ; \mathrm{B}=\mathrm{Sr}$, Ba) systems. GMS stands for "glycol-modified silane," which was used as the silicon source. Visual observation of emission light by illumination with near-UV light is also shown as the image.
[16-22] using nonvolatile and nonflammable glycol-modified silane (GMS) [16], which was uniformly dispersed in water.

The accomplishment of the reliable synthesis of silicon-containing phosphors from GMS has heralded the development of new silicon-containing phosphors by the SPS method.

In this paper, we report a process for exploring new phosphors by the SPS method based on a mineral-inspired approach. Specifically, we detail the discovery of new phosphors of silicate minerals, nepheline, i.e., $\mathrm{NaAlSiO}_{4}: \mathrm{Eu}^{2+}$ (green-yellow) [21] and benitoite, i.e., $\mathrm{BaZrSi}_{3} \mathrm{O}_{9}: \mathrm{Eu}^{2+}$ (blue-green) [22], by the SPS method utilizing water-dispersible GMS. We have first described the method for the synthesis of GMS, followed by the importance of the use of GMS in the SPS method.

\section{Glycol-Modified Silane (GMS): Water-Dispersible Silicon Compound}

Until now, we reported on the synthesis of silicon-containing phosphors [16-22] through the aqueous solution method involving GMS obtained by reacting tetraethoxysilane (TEOS) - a typical silicon alkoxide - with glycol. For example, silane modified with propylene glycol (PG) (propylene-glycol-modified-silane; PGMS) can be synthesized in the presence of hydrochloric acid as a catalyst by reacting TEOS with PG at $80^{\circ} \mathrm{C}$ for a couple of minutes. GMS has a distinct property of reacting with water to form silicon clusters [23], such as $\mathrm{Si}(\mathrm{OH})_{4}$ and $(\mathrm{OH})_{3}$-Si-O-Si $(\mathrm{OH})_{3}$, and of distributing uniformly in water, unlike other conventional $\mathrm{Si}$ compounds such as TEOS. While GMS is important in the synthesis of silicon-containing phosphor, it is indispensable in the discovery of new silicon-containing phosphors by the SPS method.

\section{Establishment of a Library of Artificial Compositions Using Minerals as Models and Search for New Phosphors}

We describe herein the conditions employed for the search of new phosphors by the SPS method. The success or failure of the search for new substances hinges on the effectiveness of the composition library that is established. We chose to use "minerals as models" in our artificial composition library. By employing the SPS method, we recently discovered $\mathrm{NaAlSiO}_{4}: \mathrm{Eu}^{2+}$ phosphor, which emits a strong green-yellow light $(553 \mathrm{~nm})$ when excited by near ultraviolet radiation of 290 to $420 \mathrm{~nm}$. We first describe the sequence of steps implemented in the discovery of the aforementioned phosphor below and, then, introduce $\mathrm{BaZrSi}_{3} \mathrm{O}_{9}: \mathrm{Eu}^{2+}$ phosphor discovered by the same method. 


\section{1. $\mathrm{NaAlSiO}_{4}: \mathrm{Eu}^{2+}$ Phosphor}

Step 1: Establishment of a library of artificial compositions using minerals as models.

First, we extracted alkaline aluminum silicate-based substances of mineral origin from the database. Eleven minerals that were specifically chosen are listed in Table 1. Additionally, two more minerals based on alkaline-earth/alkali metals and aluminum silicate, which include banalsite and stronalsite, are listed in Table 1. Of the artificial compositions in Table 1, the standard composition was created by removing water of crystallization ("•n $\mathrm{H}_{2} \mathrm{O}$ ”) from original mineral compositions. We have taken into consideration artificial solid solutions of $\mathrm{Na}$ and $\mathrm{Sr}$ in sodium-aluminum silicates assuming that a certain portion of sodium in a given sodium-aluminum silicate can be replaced by Sr. For instance, in the case of jadeite $\mathrm{NaAlSi}_{2} \mathrm{O}_{5}$, (1st column in Table 1), two possible solid solutions have been created artificially, i.e., $\mathrm{Na}_{0.95} \mathrm{Sr}_{0.05} \mathrm{Al}_{1.05} \mathrm{Si}_{1.95} \mathrm{O}_{6}$ and $\mathrm{Na}_{0.9} \mathrm{Sr}_{0.1} \mathrm{Al}_{1.1} \mathrm{Si}_{1.9} \mathrm{O}_{6}$. Owing to the mismatch in the charges between $\mathrm{Na}^{+}$and $\mathrm{Sr}^{2+}$, the charge neutrality in the artificial composition was main- tained by adjusting the molar ratio of $\mathrm{Al}$ to $\mathrm{Si}$. In the case of banalsite, $\mathrm{BaNa}_{2} \mathrm{Al}_{4} \mathrm{Si}_{4} \mathrm{O}_{16}$, two possible solid solutions, i.e., $\mathrm{Ba}_{0.8} \mathrm{Sr}_{0.2} \mathrm{Na}_{2} \mathrm{Al}_{4} \mathrm{Si}_{4} \mathrm{O}_{16}$ and

$\mathrm{Ba}_{0.6} \mathrm{Sr}_{0.4} \mathrm{Na}_{2} \mathrm{Al}_{4} \mathrm{Si}_{4} \mathrm{O}_{16}$, have been artificially created as shown in the penultimate row in Table 1. Similarly, we have constructed 27 artificial compositions, including the standard compositions. Thus, the list in Table $\mathbf{1}$ is referred to as a "composition library" inspired by minerals.

Step 2: Preparation of a mixed solution in accordance to the library of compositions.

An aqueous solution of each element that appeared in the library was prepared. The concentration of each metal was analytically determined prior to its use. In addition, an aqueous solution of europium was also prepared. The mixed solution with a composition corresponding to that mentioned in the library was prepared in a test tube, and Eu, the activator, was then added to the test tube so that its amount is $1 \mathrm{~mol} \%$ for $\mathrm{Na} / \mathrm{Sr}$ or $\mathrm{Ba} / \mathrm{Sr}$ (when necessary, charge compensation was achieved by adjusting the ratios of $\mathrm{Al}$ and $\mathrm{Si}$ ). Finally, citric acid was added as a metal stabilizer and glycol was added as a polymerizing agent.

Table 1. Library of artificial compositions inspired by natural minerals of $\mathrm{A}_{x} \mathrm{~B}_{y} \mathrm{Al}_{z} \mathrm{Si}_{q} \mathrm{O}_{w}(\mathrm{~A}=\mathrm{Li}, \mathrm{Na}, \mathrm{K}$; $\mathrm{B}=\mathrm{Sr}, \mathrm{Ba}) \mathrm{systems}$.

\begin{tabular}{|c|c|c|c|c|c|}
\hline \multirow{3}{*}{ No. } & \multirow{3}{*}{$\begin{array}{l}\text { Name of } \\
\text { Mineral }\end{array}$} & \multirow{3}{*}{$\begin{array}{l}\text { Original compositions of } \\
\text { minerals }\end{array}$} & \multicolumn{3}{|c|}{ Artificial compositions inspired by natural minerals } \\
\hline & & & \multirow{2}{*}{$\begin{array}{l}\text { Standard } \\
\text { compositions }\end{array}$} & \multicolumn{2}{|c|}{ Sr substitutions for $\mathrm{Na}$ or $\mathrm{Ba}$} \\
\hline & & & & $5 \%$ for $\mathrm{Na}$ and $20 \%$ for $\mathrm{Ba}$ & $10 \%$ for $\mathrm{Na}$ and $40 \%$ for $\mathrm{Ba}$ \\
\hline 1 & Jadeite & $\mathrm{NaAlSi}_{2} \mathrm{O}_{6}$ & $\mathrm{NaAlSi}_{2} \mathrm{O}_{6}$ & $\mathrm{Na}_{0.95} \mathrm{Sr}_{0.05} \mathrm{Al}_{1.05} \mathrm{Si}_{1.95} \mathrm{O}_{6}$ & $\mathrm{Na}_{0.9} \mathrm{Sr}_{0.1} \mathrm{Al}_{1.1} \mathrm{Si}_{1.9} \mathrm{O}_{6}$ \\
\hline 2 & Albite & $\mathrm{NaAlSi}_{3} \mathrm{O}_{8}$ & $\mathrm{NaAlSi}_{3} \mathrm{O}_{8}$ & $\mathrm{Na}_{0.95} \mathrm{Sr}_{0.05} \mathrm{Al}_{1.05} \mathrm{Si}_{2.95} \mathrm{O}_{8}$ & $\mathrm{Na}_{0.9} \mathrm{Sr}_{0.1} \mathrm{Al}_{1.1} \mathrm{Si}_{2.9} \mathrm{O}_{8}$ \\
\hline 3 & Nepheline & $\mathrm{NaAlSiO}_{4}$ & $\mathrm{NaAlSiO}_{4}$ & $\mathrm{Na}_{0.95} \mathrm{Sr}_{0.05} \mathrm{Al}_{1.05} \mathrm{Si}_{0.95} \mathrm{O}_{4}$ & $\mathrm{Na}_{0.9} \mathrm{Sr}_{0.1} \mathrm{Al}_{1.1} \mathrm{Si}_{0.9} \mathrm{O}_{4}$ \\
\hline 4 & Natrolite & $\mathrm{Na}_{2}\left[\mathrm{Al}_{2} \mathrm{Si}_{3} \mathrm{O}_{10}\right] \cdot 2 \mathrm{H}_{2} \mathrm{O}$ & $\mathrm{Na}_{2} \mathrm{Al}_{2} \mathrm{Si}_{3} \mathrm{O}_{10}$ & $\mathrm{Na}_{1.9} \mathrm{Sr}_{0.1} \mathrm{Al}_{2.1} \mathrm{Si}_{2.9} \mathrm{O}_{10}$ & $\mathrm{Na}_{1.8} \mathrm{Sr}_{0.2} \mathrm{Al}_{2.2} \mathrm{Si}_{2.8} \mathrm{O}_{10}$ \\
\hline 5 & Barrerite & $\mathrm{Na}_{2}\left[\mathrm{Al}_{2} \mathrm{Si}_{7} \mathrm{O}_{18}\right] \cdot 6 \mathrm{H}_{2} \mathrm{O}$ & $\mathrm{Na}_{2} \mathrm{Al}_{2} \mathrm{Si}_{7} \mathrm{O}_{18}$ & $\mathrm{Na}_{1.9} \mathrm{Sr}_{0.1} \mathrm{Al}_{2.1} \mathrm{Si}_{6.9} \mathrm{O}_{18}$ & $\mathrm{Na}_{1.8} \mathrm{Sr}_{0.2} \mathrm{Al}_{2.2} \mathrm{Si}_{6.8} \mathrm{O}_{18}$ \\
\hline 6 & Gobbinsite & $\mathrm{Na}_{5}\left[\mathrm{Al}_{5} \mathrm{Si}_{11} \mathrm{O}_{32}\right] \cdot 12 \mathrm{H}_{2} \mathrm{O}$ & $\mathrm{Na}_{5} \mathrm{Al}_{5} \mathrm{Si}_{11} \mathrm{O}_{32}$ & $\mathrm{Na}_{4.75} \mathrm{Sr}_{0.25} \mathrm{Al}_{5.25} \mathrm{Si}_{10.75} \mathrm{O}_{32}$ & $\mathrm{Na}_{4.5} \mathrm{Sr}_{0.5} \mathrm{Al}_{5.5} \mathrm{Si}_{10.5} \mathrm{O}_{32}$ \\
\hline 7 & Orthoclase & $\mathrm{KAlSi}_{3} \mathrm{O}_{8}$ & $\mathrm{KAlSi}_{3} \mathrm{O}_{8}$ & - & - \\
\hline 8 & Kalsilite & $\mathrm{KAlSiO}_{4}$ & $\mathrm{KAlSiO}_{4}$ & - & - \\
\hline 9 & Leucite & $\mathrm{KAlSi}_{2} \mathrm{O}_{6}$ & $\mathrm{KAlSi}_{2} \mathrm{O}_{6}$ & - & - \\
\hline 10 & Lithosite & $\mathrm{K}_{6} \mathrm{Al}_{4} \mathrm{Si}_{8} \mathrm{O}_{25} \cdot 21 \mathrm{H}_{2} \mathrm{O}$ & $\mathrm{K}_{6} \mathrm{Al}_{4} \mathrm{Si}_{8} \mathrm{O}_{25}$ & - & - \\
\hline 11 & Petalite & $\mathrm{LiAlSi}_{4} \mathrm{O}_{10}$ & $\mathrm{LiAlSi}_{4} \mathrm{O}_{10}$ & - & - \\
\hline 12 & Banalsite & $\mathrm{BaNa}_{2} \mathrm{Al}_{4} \mathrm{Si}_{4} \mathrm{O}_{16}$ & $\mathrm{BaNa}_{2} \mathrm{Al}_{4} \mathrm{Si}_{4} \mathrm{O}_{16}$ & $\mathrm{Ba}_{0.8} \mathrm{Sr}_{0.2} \mathrm{Na}_{2} \mathrm{Al}_{4} \mathrm{Si}_{4} \mathrm{O}_{16}$ & $\mathrm{Ba}_{0.6} \mathrm{Sr}_{0.4} \mathrm{Na}_{2} \mathrm{Al}_{4} \mathrm{Si}_{4} \mathrm{O}_{16}$ \\
\hline 13 & Stronalsite & $\mathrm{SrNa}_{2} \mathrm{Al}_{4} \mathrm{Si}_{4} \mathrm{O}_{16}$ & $\mathrm{SrNa}_{2} \mathrm{Al}_{4} \mathrm{Si}_{4} \mathrm{O}_{16}$ & - & - \\
\hline
\end{tabular}


Step 3: Parallel, simultaneous chemical processes, such as polyesterification (fabrication of polyester resin).

These test tubes were placed in an oven and heated, and the mixture in them was concentrated at $120^{\circ} \mathrm{C}$ for $12 \mathrm{~h}$ to promote polyesterification.

Step 4: Heat treatment processes for production of precursors and inducing fluorescence by final heat treatment.

The test tube containing polyester resin was heattreated in a sand bath at $500^{\circ} \mathrm{C}$ for $2 \mathrm{~h}$, for degreasing. The degreased substances were transferred to crucibles and fully baked in the electric furnace in the presence of graphite as a reducing agent at $1200^{\circ} \mathrm{C}$ for $2 \mathrm{~h}$ for simultaneous synthesis of many kinds of samples.

Step 5: Visual examination of light emission.

The appearance of luminescence of oxides thus obtained, through illumination by ultraviolet light (254 nm) or near-ultraviolet lights (365 nm and $400 \mathrm{~nm}$ ), is shown in Figure 2. The image clearly indicates that many of the $\mathrm{Na}(\mathrm{K}) / \mathrm{Sr}(\mathrm{Ba}) / \mathrm{Al} / \mathrm{Si}$-oxide systems are hosts for blue-toyellow luminescence originating from $\mathrm{Eu}^{2+}$.

Step 6: Choice of promising phosphors: Re-synthesis based upon rational inspection.

Phase identification by X-ray diffraction measurement and the evaluation of photoluminescence properties by excitation and emission-spectrum measurement were performed to choose promising phosphors. In the specific case of $\mathrm{Eu}^{2+}$-doped $\mathrm{Na}(\mathrm{K}) / \mathrm{Sr}(\mathrm{Ba}) / \mathrm{Al} / \mathrm{Si}$-oxide systems, further reduction of a stable trivalent europium $\left(\mathrm{Eu}^{3+}\right)$ to a less stable divalent europium $\left(\mathrm{Eu}^{2+}\right)$ was found to be necessary. In order to reduce $\mathrm{Eu}^{3+}$ to $\mathrm{Eu}^{2+}$ completely, additional heat-treatment under a strongly reducing atmosphere was carried out by passing $\mathrm{N}_{2} / \mathrm{NH}_{3}(90 / 10$ mol\%) gas at $1200^{\circ} \mathrm{C}$ for $2 \mathrm{~h}$. As expected, the luminescence characteristics were significantly improved due to the increased amount of available $\mathrm{Eu}^{2+}$. Figure 3 shows images depicting luminescence of some representative samples after reduction by $\mathrm{N}_{2} / \mathrm{NH}_{3}$. The nepheline sample with the nominal composition of $\mathrm{NaAlSiO}_{4}: \mathrm{Eu}^{2+}$, the natrolite sample with the nominal composition of $\mathrm{Na}_{2} \mathrm{Al}_{2} \mathrm{Si}_{3} \mathrm{O}_{10}: \mathrm{Eu}^{2+}$, and their Sr-substituted derivatives emit strong green-to-yellow lights when illumination with UV/near-UV lights between $254 \mathrm{~nm}$ and $400 \mathrm{~nm}$. Careful phase identification by X-ray diffraction indicated that while $\mathrm{NaAlSiO}_{4}$ was found in the nepheline sample, the same was not true for the natrolite sample; instead a mixed phase of $\mathrm{NaAlSiO}_{4}$ and $\mathrm{SiO}_{2}$ formed. These observations led us to the conclusion that it is nepheline that emits strong green-to-yellow lights in samples with the nominal compositions of $\mathrm{NaAlSiO}_{4}: \mathrm{Eu}^{2+}$ and $\mathrm{Na}_{2} \mathrm{Al}_{2} \mathrm{Si}_{3} \mathrm{O}_{10}: \mathrm{Eu}^{2+}$.

The excitation and emission spectra of the $\mathrm{NaAlSiO}_{4}: \mathrm{Eu}^{2+}$ phosphor discovered in the aforementioned manner are shown in Figure 4. While this phosphor displays weak emission when excited by visible light, it emits strong green-yellowish light with excitation by near ultraviolet light of $320 \mathrm{~nm}$. In addition, the emission spectrum is comprised of one simple broad component with a peak maximum at $553 \mathrm{~nm}$.

Our future goal is to achieve a redshift (long-wavelength shift) in an excitation spectrum. In oxynitride, wherein a portion of oxygen was replaced with nitrogen, a redshift in the excitation spectrum was observed along with a slight increase in intensity at $400 \mathrm{~nm}$ [21].

\section{2. $\mathrm{BaZrSi}_{3} \mathrm{O}_{9}: \mathrm{Eu}^{2+}$ Phosphor}

Like in the case of $\mathrm{NaAlSiO}_{4}$, we extracted zirconium (titanium) silicate-based substances of mineral origin from the database. Of the elements present in original mineral compositions, we replaced those that were un-

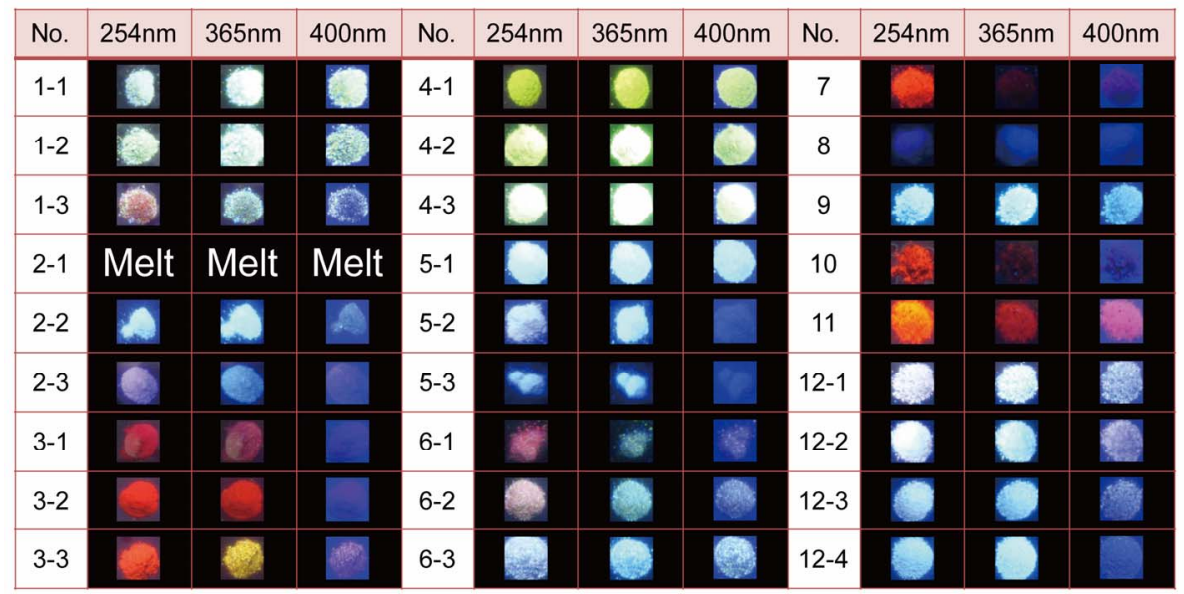

Figure 2. Appearance of luminescence in a series of samples (corresponding to the compositions listed in Table 1) synthesized by the SPS method, upon illumination of the samples with ultraviolet light (254 nm) or near-ultraviolet light (365 $\mathrm{nm}$ and 400 nm). 


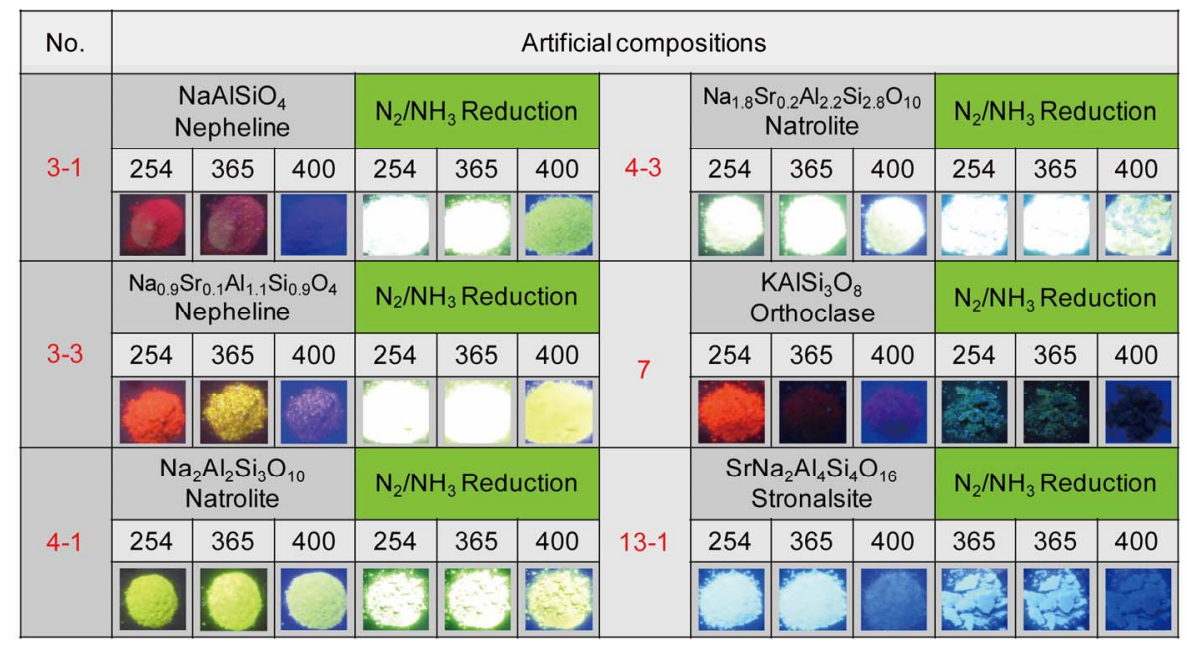

Figure 3. Appearance of luminescence in some representative samples upon illumination of the samples with ultraviolet light $(254 \mathrm{~nm})$ or near-ultraviolet light $(365 \mathrm{~nm}$ and $400 \mathrm{~nm})$ before and after reduction by $\mathrm{N}_{2} / \mathrm{NH}_{3}$. Figures on each image indicate the wavelength $(\mathrm{nm})$ used for excitation.

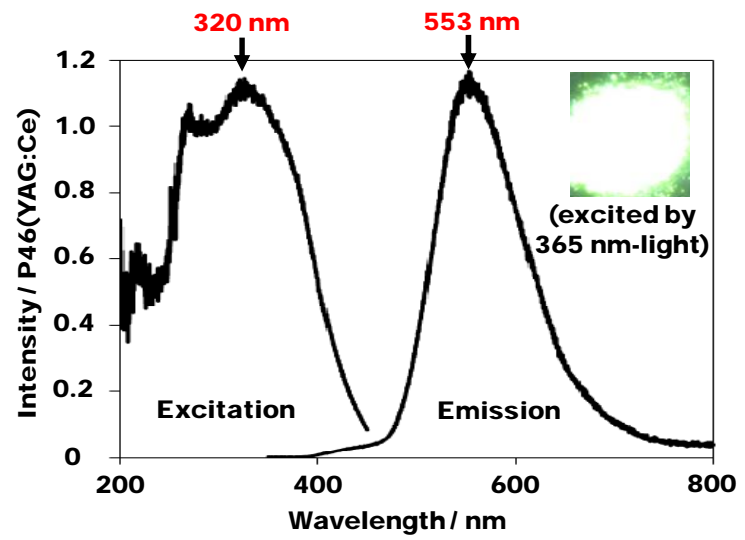

Figure 4. Excitation and emission spectra of the nephelineorigin $\mathrm{NaAlSiO}_{4}: \mathrm{Eu}^{2+}(1 \mathrm{~mol} \%$ for $\mathrm{Na})$ discovered by employing the SPS method.

suitable for phosphors. For instance, Fe and Ti were replaced with elements having similar ionic radii such as $\mathrm{Mg}$ and $\mathrm{Zr}$, respectively. We replaced the removed artificial composition for water of crystallization ("• $\mathrm{nH}_{2} \mathrm{O}$ ”). In addition, we took into consideration the solid solutions comprising alkaline earth metals $\mathrm{Ca}, \mathrm{Sr}$ and $\mathrm{Ba}$ and alkali metals Li, Na, and K. Thus, as depicted in Table 1, 49 artificial compositions were established using each mineral as a model, and a part of the artificial composition library established in this way is shown in Table 2. As in the case of $\mathrm{NaAlSiO}_{4}$, we employed $\mathrm{Eu}^{2+}$ as an activator for all the 49 artificial compositions (typically $3 \mathrm{~mol} \%$ $\mathrm{Eu}^{2+}$ for $\mathrm{Na}$ or $\left.\mathrm{Ba}\right)$.

After careful inspection of the result obtained by the SPS experiment, the $\mathrm{BaZrSi}_{3} \mathrm{O}_{9}: \mathrm{Eu}^{2+}$ phosphor, emitting blue-green light (480 $\mathrm{nm}$ ), was found. Its emission intensity was comparable to the maximum intensity of a commercially available BAM ( $\mathrm{BaMgAl}_{10} \mathrm{O}_{17}: \mathrm{Eu}^{2+}$ ) pho- sphor. The light emission when irradiated with $405 \mathrm{~nm}$ of near ultraviolet light is shown in Figure 5, and the excitation and emission spectra of the same sample are shown in Figure 6 in comparison with that of BAM. It is worthwhile to note that in contrast to BAM, a flat excitation spectrum was observed for $\mathrm{BaZrSi}_{3} \mathrm{O}_{9}: \mathrm{Eu}^{2+}$ over the range of $290 \mathrm{~nm}$ to $420 \mathrm{~nm}$. The intensity of luminescence due to excitation with $405 \mathrm{~nm}$ was more than twice that of BAM. In conclusion, $\mathrm{BaZrSi}_{3} \mathrm{O}_{9}: \mathrm{Eu}^{2+}$ is considered to be useful as a blue-green phosphor for use in near-ultraviolet LEDs [22,24].

\section{Concluding Remarks}

We believe that research involving exploration for new phosphors is still in infancy. The key features that are common to the currently known useful phosphors are cations of elements such as silicon, phosphorus, aluminum, gallium, alkaline earth metals, and alkali metals, and anions of elements such as oxygen, nitrogen, sulfur, and halogens. The possible combinations of these elements result in astronomical options. As a result, no one can deny the possibility of the existence of new substances and new phosphors. The principle of synthesis of inorganic phosphors, which are categorized as ceramics, differs fundamentally from organic chemical synthesis on the basis of the reaction between molecules. Further, due to slow movement of cations in the solid lattice, inorganic phosphor synthesis is not simple and generally spans a long duration. Moreover, while in organic synthesis, it is possible to refine the final product by techniques such as chromatography, in phosphor synthesis, it is almost impossible to refine only the target phase separately, if a mixed phase sample is obtained. Unless these fundamental challenges are redressed in phosphor syn- 
Table 2. Library of artificial compositions inspired by natural minerals of zirconium (titanium) silicate systems.

\begin{tabular}{|c|c|c|c|c|}
\hline \multirow{2}{*}{ No. } & \multirow{2}{*}{ Name of Mineral } & \multirow{2}{*}{$\begin{array}{l}\text { Original compositions of } \\
\text { minerals }\end{array}$} & \multicolumn{2}{|c|}{$\begin{array}{l}\text { Artificial compositions inspired by } \\
\text { natural minerals }\end{array}$} \\
\hline & & & Standard compositions & Solid solutions \\
\hline 1 & Armstrongite & $\mathrm{CaZrSi}_{6} \mathrm{O}_{15} \cdot 2.5 \mathrm{H}_{2} \mathrm{O}$ & $\mathrm{CaZrSi}_{6} \mathrm{O}_{15}$ & $(\mathrm{Ca}, \mathrm{Sr}) \mathrm{ZrSi}_{6} \mathrm{O}_{15}$ \\
\hline 2 & Benitoite & $\mathrm{BaZrSi}_{3} \mathrm{O}_{9}$ & $\mathrm{BaZrSi}_{3} \mathrm{O}_{9}$ & $(\mathrm{Ba}, \mathrm{Sr}) \mathrm{ZrSi}_{3} \mathrm{O}_{9}$ \\
\hline 3 & Calciohilairite & $\mathrm{CaZrSi}_{3} \mathrm{O}_{9} \cdot \mathrm{H}_{2} \mathrm{O}$ & $\mathrm{CaZrSi}_{3} \mathrm{O}_{9}$ & $(\mathrm{Ca}, \mathrm{Sr}) \mathrm{ZrSi}_{3} \mathrm{O}_{9}$ \\
\hline 4 & Cataplelite & $\mathrm{Na}_{2} \mathrm{ZrSi}_{3} \mathrm{O}_{9} \cdot 2 \mathrm{H}_{2} \mathrm{O}$ & $\mathrm{Na}_{2} \mathrm{ZrSi}_{3} \mathrm{O}_{9}$ & $(\mathrm{Na}, \mathrm{Li})_{2} \mathrm{ZrSi}_{3} \mathrm{O}_{9}$ \\
\hline 5 & Elpidite & $\mathrm{Na}_{2} \mathrm{ZrSi}_{6} \mathrm{O}_{15} \cdot 3 \mathrm{H}_{2} \mathrm{O}$ & $\mathrm{Na}_{2} \mathrm{ZrSi}_{6} \mathrm{O}_{15}$ & $(\mathrm{Na}, \mathrm{K})_{2} \mathrm{ZrSi}_{6} \mathrm{O}_{15}$ \\
\hline 6 & Parakeldyshite & $\mathrm{Na}_{2} \mathrm{ZrSi}_{2} \mathrm{O}_{7}$ & $\mathrm{Na}_{2} \mathrm{ZrSi}_{2} \mathrm{O}_{7}$ & $(\mathrm{Na}, \mathrm{K})_{2} \mathrm{ZrSi}_{2} \mathrm{O}_{7}$ \\
\hline 7 & Terskite & $\mathrm{Na}_{4} \mathrm{ZrSi}_{6} \mathrm{O}_{16} \cdot 2 \mathrm{H}_{2} \mathrm{O}$ & $\mathrm{Na}_{4} \mathrm{ZrSi}_{6} \mathrm{O}_{16}$ & $(\mathrm{Na}, \mathrm{Li})_{4} \mathrm{ZrSi}_{6} \mathrm{O}_{16}$ \\
\hline 8 & Aenigmatite & $\mathrm{Na}_{2} \mathrm{Fe}_{5} \mathrm{TiSi}_{6} \mathrm{O}_{20}$ & $\mathrm{Na}_{2} \mathrm{Mg}_{5} \mathrm{ZriSi}_{6} \mathrm{O}_{20}$ & $(\mathrm{Na}, \mathrm{Li})_{2} \mathrm{Mg}_{5} \mathrm{ZriSi}_{6} \mathrm{O}_{20}$ \\
\hline 9 & Titanite & $\mathrm{CaTiSiO}_{5}$ & $\mathrm{CaZrSiO}_{5}$ & $(\mathrm{Ca}, \mathrm{Sr}) \mathrm{ZrSiO}_{5}$ \\
\hline 10 & Natisaite & $\mathrm{Na}_{2} \mathrm{TiSiO}_{5}$ & $\mathrm{Na}_{2} \mathrm{ZrSiO}_{5}$ & $(\mathrm{Na}, \mathrm{K})_{2} \mathrm{ZrSiO}_{5}$ \\
\hline
\end{tabular}

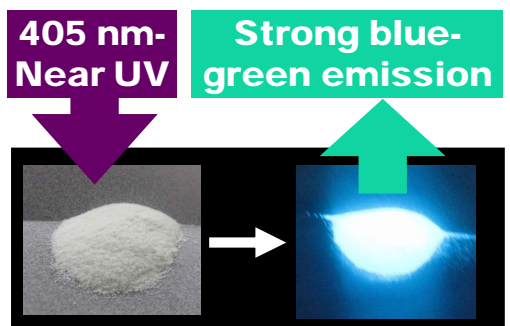

(a)

(b)

Figure 5. Appearance of the powder of $\mathrm{BaZrSi}_{3} \mathrm{O}_{9}: \mathrm{Eu}^{2+}$ (a) and its emission by illumination of $400 \mathrm{~nm}$ light (b).

thesis, unearthing new phosphors prepared from silicates, expected to have wide-ranging functions, is doubtful.

In this paper, we described the process parameters involved in the exploration of new phosphors using the SPS method based on a mineral-inspired approach. We would like to reiterate the importance of glycol-modified silane (GMS) in the implementation of the SPS method for preparing new phosphors from silicates. Using this method, we recently found $\mathrm{Eu}^{2+}$-activated oxide phosphor that emitted red-orange light (625 nm) when excited with blue light [25]. Moreover, we are currently developing new phosphorus-containing phosphors using new phosphate compounds applicable to the SPS method [26]. It is expected that the SPS method will become popular in the near future and this will inject new vigor into the field of phosphor exploration.

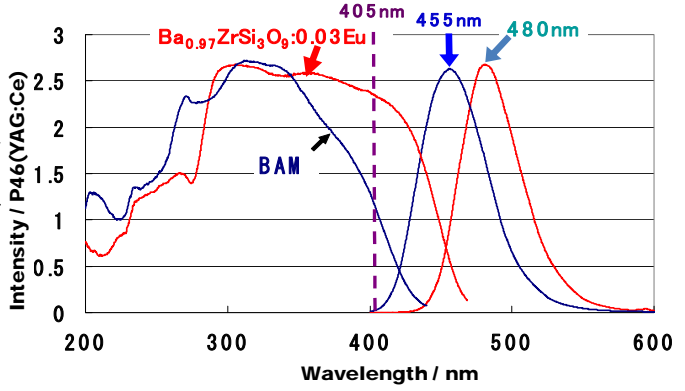

Figure 6. Excitation and emission spectra of the benitoiteorigin $\mathrm{BaZrSi}_{3} \mathrm{O}_{9}: \mathrm{Eu}^{2+}$ (3 mol\% for $\mathrm{Ba}$ ) discovered by employing the SPS method.

\section{Acknowledgements}

This work was partly supported by the Ministry of Education, Culture, Sports and Technology, Japan through Grant-in-Aids for Scientific Research on Innovative Areas of "Fusion Materials" (No. 2206) and on Scientific Research A (No. 22246081).

\section{REFERENCES}

[1] O. V. Buyevskaya, A. Bruckner, E. V. Kondratenko and D. Wolf and M. Baerns, "Fundamental and Combinatorial Approaches in the Search for and Optomization of Catalytic Materials for the Ozidative Dehydrogenation of Propane to Propene,” Catalysis Today, Vol. 67, No. 4, 2001, pp. 369-378.

http://dx.doi.org/10.1016/S0920-5861(01)00329-7 
[2] D. Wolf, O. V. Buyevskaya and M. Baerns, “An Evolutionary Approach in the Combinatorial Selection and Opromization of Catalytic Materials,” Applied Catalysis A, Vol. 200, No. 1-2, 2000, pp. 63-77. http://dx.doi.org/10.1016/S0926-860X(00)00643-8

[3] J. S. Paul, R. Janssens, J. F. M. Denayer, G. V. Baron and P. A. Jacobs, “Optimization of MoVSb Oxide Catalyst for Partial Oxidation of Isobutane by Combinatorial Approaches," Journal of Combinatorial Chemistry, Vol. 7, No. 3, 2005, pp. 407-413. http://dx.doi.org/10.1021/cc0500046

[4] K. S. Sohn, D. H. Park, S. H. Cho, J. S. Kwak and J. S. Kim, "Computational Evolutionary Optimization of Red Phosphor for Use in Tri-Color White LEDs," Chemistry of Materials, Vol. 18, No. 7, 2006, pp. 1768-1772. http://dx.doi.org/10.1021/cm052179o

[5] K. S. Sohn, D. H. Park, S. H. Cho, B. I. Kim and S. I. Woo, "Generic Algorithn-Assisted Combinatorial Search for a New Green Phosphor for Use in Tricolor White LEDs," Journal of Combinatorial Chemistry, Vol. 8, No. 1, 2006, pp. 44-49.

http://dx.doi.org/10.1021/cc050101z

[6] K. S. Sohn, J. M. Lee and N. Shin, "A Search for New Red Phosphors Using a Computational Evolutionary Optimization Process,” Advanced Materials, Vol. 15, No. 24, 2003, pp. 2081-2084.

[7] K. S. Sohn, B. I. Kim and N. Shin, "Generic Algorithm-Assisted Combinatorial Search for New Red Phosphors of High Efficiency at Soft Ultraviolet Excitation,” $J$. Electrochem. Soc., Vol. 151, No. 12, 2004, H243-H248. http://dx.doi.org/10.1149/1.1808592

[8] Y. S. Jung, C. Kulshreshtha, J. S. Kim, N. Shin and K. S. Sohn, "Generic Algorithm-Assisted Combinatorial Search for New Blue Phosphors in a (Ca,Sr,Ba,Mg,Eu $)_{x} \mathrm{~B}_{y} \mathrm{P}_{z} \mathrm{O}_{d}$ System," Chemistry of Materials, Vol. 19, No. 22, 2007, pp. 5309-5318. http://dx.doi.org/10.1021/cm070976b

[9] J. Kennedy and R. Eberhart, "Particle Swarm Optimization," IEEE International Conference on Neural Networks, Perth, Vol. 4, 27 November-1 December1995, pp. 1942-1948. http://dx.doi.org/10.1109/ICNN.1995.488968

[10] W. B. Park, Y. S. Jeong, S. P. Singh and K. S. Sohn, “A Yellow-Emitting Oxynitride Phosphor: $\mathrm{Ce}_{4-x} \mathrm{Ca}_{x} \mathrm{Si}_{12} \mathrm{O}_{3+\chi} \mathrm{N}_{18-x}: \mathrm{Eu}^{2+}$," ECS Journal of Solid State Science and Technology, Vol. 2, No. 2, 2013, pp. R3100R3106. http://dx.doi.org/10.1149/2.013302jss

[11] Y. Suzuki and M. Kakihana, "Parallel Solution-Based Synthesis Approach for Search of Lanthanoid-Activated $\mathrm{Ca}_{2} \mathrm{SnO}_{4}$ Phosphor Materials," Journal of the American Ceramic Society, Vol. 92, Suppl. s1, 2009, pp. S168-S171. http://dx.doi.org/10.1111/j.1551-2916.2008.02706.x

[12] M. Kakihana, "Synthesis of High-Performance Ceramics Based on Polymerizable Complex Method," Journal of the Ceramic Society of Japan, Vol. 117, No. 8, 2009, pp. 857-862. http://dx.doi.org/10.2109/jcersj2.117.857

[13] M. Kakihana and M. Yoshimura, "Synthesis and Characteristics of Complex Multicomponent Oxides Prepared by Polymer Complex Method," Bulletin of the Chemical Society of Japan, Vol. 72, No. 7, 1999, pp. 1427-1443. http://dx.doi.org/10.1246/bcsj.72.1427
[14] M. Kakihana, "Sol-Gel Preparation of High Temperature Superconducting Oxides,” Journal of Sol-Gel Science and Technology, Vol. 6, No. 1, 1996, pp. 7-55.

[15] Inorganic Crystal Structure Database (ICSD), compiled by Das Fachinformationszentrum (FIZ) Karlsruhe (in Germany) and National Institute of Standard and Technology (in United States of America) in 2012.

[16] Y. Suzuki and M. Kakihana, "Preparation of Water Soluble Silicon Compound and its Application for Synthesis of (Y, Ce, $\mathrm{Gd})_{2} \mathrm{SiO}_{5}$ Blue Emission Phosphor," Journal of the Ceramic Society of Japan, Vol. 117, No. 3, 2009, pp. 330-334. http://dx.doi.org/10.2109/jcersj2.117.330

[17] Y. Suzuki and M. Kakihana, "New Water Soluble and Handy Silicon Precursor for Synthesis of (Y, Ce, $\mathrm{Gd})_{2} \mathrm{SiO}_{5}$ Phosphor," IOP Conference Series: Materials Science and Engineering, Vol.1, No. 1, 2009, p. 012012. http://dx.doi.org/10.1088/1757-8981/1/1/012012

[18] N. Takahashi, Y. Suzuki and M. Kakihana, "Synthesis of $\mathrm{Zn}_{2} \mathrm{SiO}_{4}: \mathrm{Mn}^{2+}$ Green Emission Phosphor by Hydrothermal Gelation Method Using a Novel Water Soluble Silicon Compound," Journal of the Ceramic Society of Japan, Vol. 117, No. 3, 2009, pp. 313-315. http://dx.doi.org/10.2109/jcersj2.117.313

[19] K. Yoshizawa, H. Kato, M. Kakihana, "Synthesis of $\mathrm{Zn}_{2} \mathrm{SiO}_{4}: \mathrm{Mn}^{2+}$ by Homogeneous Precipitation Using Propylene Glycol-Modified Silane,” Journal of Materials Chemistry, Vol. 22, No. 33, 2012, pp. 17272-17277. http://dx.doi.org/10.1039/c2jm33056c

[20] C. Yasushita, H. Kato and M. Kakihana, "Synthesis of an Oxynitride-Based Green Phosphor $\mathrm{Ba}_{3} \mathrm{Si}_{6} \mathrm{O}_{12} \mathrm{~N}_{2}$ : $\mathrm{Eu}^{2+}$ via an Aqueous Solution Process Using Propylene GlycolModified Silane,” Journal of the Society for Information Display, Vol. 13, No. 3, 2012, pp. 107-111. http://dx.doi.org/10.1080/15980316.2012.692725

[21] J. Kim, H. Kato and M. Kakihana, "Control of NaAl$\mathrm{SiO}_{4}: \mathrm{Eu}^{2+}$ Photoluminescence Properties by Charge-Compensated Aliovalent Element Substitutions," Journal of the Society for Information Display, Vol. 13, No. 3, 2012, 97-100. http://dx.doi.org/10.1080/15980316.2012.691079

[22] T. Komukai, Y. Takatsuka, K. Yoshizawa, S. Tezuka, H. Kato and M. Kakihana, "Synthesis and Luminescence Properties of $\mathrm{BaZrSi}_{3} \mathrm{O}_{9}$ :Eu by Aqueous Solution Method Using Water-Soluble Silicon Compounds," The Electrochemical Society of Japan, Vol. 338, 2011, pp. 19-23.

[23] D. Yoshihara, M. Kobayashi, H. Kato and M. Kakihana, "Development and Characterization of Novel Water-Soluble Silicon Compounds," Proceedings for the 29th International Korea-Japan Seminar on Ceramics (KJ Ceramics 29), Poster No. PS02-8, 2012.

[24] D-Y. Wang, C.-H. Huang, Y.-C. Wu and T.-M. Chen, " $\mathrm{BaZrSi}_{3} \mathrm{O}_{9}: \mathrm{Eu}^{2+}$ : A Cyan-Emitting Phosphor with High Quantum Efficiency for White Light-Emitting Diodes," Journal of Materials Chemistry, Vol. 21, No. 29, 2011, pp. 10818-10822. http://dx.doi.org/10.1039/c1jm00080b

[25] S. Tezuka, Y. Sato, T. Komukai, Y. Takatsuka, H. Kato and M. Kakihana, " $\mathrm{Eu}^{2+}$-Activated $\mathrm{CaSrSiO}_{4}$ : A New Red-Emitting Oxide Phosphor for White-Light-Emitting Diodes”, Applied Physics Express, Vol. 6, No. 7, 2013, Article ID: 072101. 
http://dx.doi.org/10.7567/APEX.6.072101

[26] M. Kim, M. Kobayashi, H. Kato and M. Kakihana, "Enhancement of Luminescence Properties of a $\mathrm{KSrPO}_{4}$ : $\mathrm{Eu}^{2+}$ Phosphor Prepared Using a Solution Method with a
Water-Soluble Phosphate Oligomer", Journal of Materials Chemistry C, Vol. 1, No. 36, 2013, pp. 5741-5746. http://dx.doi.org/10.1039/c3tc31121j 